\title{
Türkiye'de Sosyoloji Bölümleri Arasında İstihdam Örüntüleri: Sosyal Ağ Analizi Üzerinden Bir Değerlendirme
}

\section{Employment Patterns Among Sociology Departments in Turkey: An Evaluation Through Social Network Analysis}

\author{
Emin Baki Adaş ${ }^{1}$
}

Başvuru Tarihi: 06.02.2018

Kabul Tarihi: 09.04.2019

\section{Öz}

Bu makale, Türkiye'de sosyolojinin kurumsal gelişmesini bölümler arası istihdam örüntüleri üzerinden değerlendirmeyi amaçlamaktadır. Yazı, Türkiye'de salt akademik istihdam piyasasının niteliğini anlamanın ötesinde bir amaç taşımaktadır. Sıklıkla Türkiye sosyolojisi için dile getirilen "bölmelenmişlik" veya "süreksizlik" gibi tespitlerin işaret ettiği akademik okul/ekollerin veya akademik bir habitus oluş(a)maması sorununa bölümler arası akademik üretim ve istihdam örüntülerinin sosyal network analizi üzerinden bir katkı yapmayı hedeflemektedir. Son yıllarda, bölümler arası etkileşim ve istihdam örüntüsü, özellikle merkezdeki bölümler ile çevrede yer alan bölümler arasındaki artan akademik hareketlilik ve etkileşimin, "bölmelenmişlik sorununu" aşması yönünde maddi bir altyapının imkanlarını barındırmakla birlikte, ne 'merkez'de konumlanan üniversiteler ve bölümler, ne de 'çevre'deki üniversite ve bölümler açısından akademik bir gelenek veya "epistemik cemaat" oluşması yönünde bir niteliğe dönüşmemiştir. Ne merkezdeki görece yüksek homojen yapı, ne de çevredeki farklı istihdam modellerinin sonucunda oluşan heterojen yapı bölmelenmişlik sorununu aşamamıştır. Bu niteliğiyle Türkiye'de sosyoloji, artan etkileşime rağmen bölmelenmişlik sorununu aşabildiğini söylemek mümkün görünmemektedir. Bu durum bir anomaliden ziyade cari akademik işleyişin bir sonucu olarak değerlendirilmelidir: Bunun en önemli nedeni ise, sosyoloji bölümlerinin kuruluşundan itibaren akademik üretim ve istihdam süreçlerinde bölümlerin özerkliğinin olmaması ve iktidarın müdahalelerine sürekli açık olmasının bir sonucudur.

Anahtar Kelimler: Türkiye'de Sosyoloji, Akademik İstihdam, Sosyal Network Analizi, Bölmelenmişlik

\footnotetext{
${ }^{1}$ Adnan Menderes Üniversitesi Fen Edebiyat Fakültesi, eminadas@gmail.com, ORCID: 0000-0002-9360-5804
} 


\section{Abstract}

This article aims to analyze institutional development of sociology through academic employment patterns among sociology departments in Turkey. The article is not simply concerned with the nature of academic labor market but it rather aims to contribute to the debates within Turkish sociology on "compartmentalization" and "discontinuity" which conceptualizes the lack of academic traditions, schools, or habitus in Turkish sociology through social network analysis. The article demonstrates that even though the material infrastructure of sociology networks provides potentiality to overcome the "compartmentalization problem" as a result of increased interactions among departments through academic mobility in last two decades, neither in the universities at the center, nor those in the periphery, have been able to translate this possibility to create an "epistemic community" or academic schools/traditions. Neither high homogeneity of academic institutional background of academics at the center, nor heterogeneity of academic institutional background of academics at the periphery has been able to overcome this "compartmentalization". The article argues that the question of compartmentalization is not an "anomaly" but it is institutional outcome of the state interferences in academic employment and academic production since the establishment of sociology departments which undermined the academic autonomy of the departments and universities.

Keywords: Sociology in Turkey, Academic Employment, Social Network Analysis, compartmentalization

\section{Giriş}

Üniversite yapısı içinde akademik bir disiplin olarak kurulan sosyolojinin Türkiye'deki tarihi yüzyıllık bir geçmişe sahiptir. Bu uzun geçmişe rağmen Türkiye sosyolojisinde "bölmelenmişlik" veya "süreksizlik" olarak da tarif edilen düşünce geleneklerinin veya akademik bir habitusun oluş(a)madığı yaygın kabul gören tezlerinden biridir (Akşit, 1986; Kayalı 1997; 2000). Bölmelenmişlik sorunu, hem kuşaklar arasında, hem bölümler arasında ve hem de aynı bölüm içinde akademisyenler arasındaki epistemik kopukluk ya da süreksizlik olarak tanımlanabilir (Akşit 1986). Son yıllar akademik kurumlar arasında artan akademik hareketlilik ve etkileşimlerin bu bölmelenmişlik sorununu aşma yönünde maddi bir altyapı oluşturmaktadır. Zira, son yılarda kurulan yeni devlet ve vakıf üniversitelerinde açılan sosyoloji bölümlerinin öğretim elemanı ihtiyacını karşılamaya dönük gerek yurt-dışına burslu öğrenci göndermek şeklinde, gerek ülke içinde doktora programlarının teşvik edilmesi ve desteklenmesi ile birlikte sosyoloji bölümleri arasında eleman ve öğrenci değişimlerinin ve etkileşimlerinin arttı̆̆ gözlemlenmektedir. Diğer taraftan, sayıları hızla artan vakıf ve özel üniversitelerin bünyesinde kurulan bölümlerin rekabetçi istihdam politikaları merkezde konumlanan üniversitelerden yeni kurulan üniversitelere doğru kıdemli öğretim elemanı transferi ve hareketliliğini de arttırmıştır. Ayrıca, son dönemde sayıları hızla artan konferans ve kongre gibi akademik organizasyonlar öğretim üyeleri arasında hem kişisel hem de akademik iş birliklerinin gelişmesi yönünde imkân ve potansiyelleri geçmiş yıllara göre arttırmıştır. Tüm bu gelişmeler bölümler arası etkileşim ve istihdam örüntüsü, özellikle merkezdeki bölümler ile 
çevrede yer alan bölümler arasındaki artan akademik hareketlilik ve etkileşim karmaşı bir bölümler arası ilişki ağının ortaya çıkmasına yol açmıştır.

$\mathrm{Bu}$ çalışma, Türkiye'de kamu ve özel/vakıf üniversiteleri bünyesinde kurulan sosyoloji bölümlerinde aktif olarak çalışan öğretim üyelerinin lisans ve doktora derecelerini aldıkları ve görev yaptıkları kurumlar bazında ortaya çıkan karmaşık istihdam örüntüleri üzerinden Türkiye sosyolojisinde bölümler arasındaki istihdam örüntüsünün yapısal bir analizini yapmayı hedeflemektedir. Makale sosyal network analiz yöntemini kullanarak, hem Türkiye sosyolojisine ilişkin yaygın olarak dile getirilen "bölmelenmişlik sorunu" üzerine yapısal bazı değerlendirmeler yapmayı, hem de Türkiye'de sosyoloji özelinde ortaya çıan akademik istihdam örüntülerindeki temel eğilim ve yönelimleri ortaya koymayı amaçlamaktadır.

Çalışma dört ana bölümden oluşmaktadır. Birinci bölümde, çalışmada kullanılan yöntem ve veri ele alınmaktadır. Sosyal network analizi, ilişkisel verilerden hareketle sosyal yapıların ampirik olarak ortaya konmasına ve analiz edilmesine uygun bir yöntem olması nedeniyle tercih edilmiştir. İkinci bölüm bugüne kadar zengin bir araştırma alanı olarak ortaya çıkan Türkiye sosyolojisinin sosyolojisi üzerine yapılan çalışmaları kısaca özetlemekte ve bu çalışmalarda ortaya çıkan temel tespitleri değerlendirmektedir. Üçüncü bölüm, Türkiye'de sosyolojinin yüzyıllık kurumsal gelişmesinin ana hatlarını ortaya koymaktadır. Dördüncü bölümde ise, Türkiye'deki farklı akademik istihdam modelleri ve sosyoloji bölümleri arasında ortaya çıkan istihdam örüntüsünü veriler ve verilerin ortaya koyduğu bulgular ışı̆̆ında analiz etmektedir.

\section{Çalışmanın Yöntemi ve Veri}

$\mathrm{Bu}$ çalışma, 93 sosyoloji bölümünde toplam 750 öğretim üyesini kapsayan, bölümler arası akademik istihdam örüntüsünü sosyal network analizi üzerinden değerlendirilmesini amaçlamaktadır. Çalışmada kullanılan veriler, 2015 yılında farklı sosyoloji bölümlerinde aktif olarak görev yapan 750 öğretim üyesinin lisans ve doktoralarını yaptıkları bölüm ve/veya ülkelere ilişkin verilerin akademik özgeçmişler üzerinden derlenmesine dayanmaktadır. Sosyal network analizi, klasik istatistiki analiz tekniklerin farklı bir metodoloji ve analiz tekniğine dayanır. Klasik istatistiki analizler, değişkenler ve değişkenler arası ilişkilerin yığınsal analizine dayanır. Sosyolojide ya da diğer toplumsal araştırmalarda kullanılan ampirik araştırma yöntemlerinde veriler, kişilerin veya kurumların birtakım özelliklerini tarif eden değişkenler üzerinden gerçekleştirilir. Dolayısıyla, analiz aktörler arası ilişkiden daha ziyade aktörlerin bir dizi özelliklerini tarif eden değişkenler arası ilişkiyi betimler. Toplumsallık yani aktörler arası ilişkisellik ampirik olarak gösterilemez. İlişkisellik teoriktir veya varsayımsaldır (Dépelteau ve Powell, 2013).

Buna karşlık, sosyal network analizi ilişkisel veriye dayanır. Aktörlerin veya kurumların toplumsal uzaydaki konumları ve ilişkilerinin ampirik verisi üzerinden aktörlerin ilişkileri, konumları ve özellikleri analize tabi tutulur. Burada toplumsallık salt teorik olmaktan daha ziyade, ampiriktir. Sosyal network analizi, aktörler arasında ilişki, ilişkinin niteliği, sıklığı, yönü 
ve aktörlerin özelliklerinin tümünü matris şeklinde düzenlenen ve maddi ya da bilişsel/sembolik yönelimlerin haritalarının ortaya konmasına olanak tanıyan bir analiz tekniğidir (Scott, 2000; Wasserman ve Faust, 1994). Sosyal A $\breve{g}$ analizinde, düğmeler (nodes) aktörleri temsil ederken, çizgiler (edges) ise aktörler arasındaki ilişkiyi gösterir. Bu çalışmada ağ analizi, UCINET 6.0 ve Gephi 9.0 network programları kullanılarak yapılmıştır.

\section{Türkiye Sosyolojisi Üzerine Çalışmalar}

Türkiye'de sosyolojinin gelişimi üzerine oldukça kapsamlı ve zengin bir literatür mevcuttur. Bu çalışmaları dört ana başlık altında sınıflandırmak mümkündür. Bu literatür içinde nicelik olarak en fazla paya sahip olan birinci gruptaki çalışmalar, "entelektüel biyografi” niteliği taşımaktadır. Sosyoloji tarihi içinde öne çıkan önemli kişilerin ele alındığı bu çalışmalar, kişilerin içinde yaşadığı tarihsel-toplumsal çevre, etkilendiği düşünce akımları, sosyoloji gelenekleri, Türkiye'de sosyolojiye katkıları ve etkileri şeklindedir (Kongar, 1998; Özdemir, 2008). İkinci gruptaki çalışmaları ise "dönem incelemeleri” olarak tanımlayabiliriz. Türkiye toplumunun ekonomik, siyasal ve kültürel değişimleri bağlamında sosyolojiyi ele alan bu çalışmalar, dönemsel olarak öne çıkan farklı tema ve çalışma alanlarının hem tematik analizi hem de bu dönemde başat sosyal bilimcilerin sosyolojiye yaklaşım ve katkıların değerlendirildiği incelemelerdir (Kaçmazoğlu, 2003; 2010; Akpolat, 2013; Ergun, 1985). Üçüncü gruptaki çalışmalar, bölüm tarihçelerinin ele alındığı monografiler olarak tanımlanabilir. Bölüm tarihçeleri üzerine çalışmalar oldukça sınırlı sayıdadır (Çoşkun, 1991; Kaya, 2008; Kasapoğlu, 1999). Dördüncü grupta yer alan çalışmalar ise, son yıllarda Türkiye sosyolojisinin bütüncül bir değerlendirmesini yapmaya çalışan, başat eğilim ve sorunların tespit edilmesine dönük metaanaliz çabalarının ön plana çıktığı inceleme ve araştırmalardır (Akşit, 1986; Kayalı, 2000; Aktay, 2013; Alver, 2014).

Bir kategori olarak genelde Türkiye'de entelektüellerin, özelde ise sosyologların bilgi ve düşünceye dönük yaklaşım ve tutumlarının niteliğini ortaya koymaya çalışan bu analizler, Türkiye'de sosyolojiye ve entelektüellere dair bir dizi genel tespitler yapmaktadır. Örneğin Akşit, Türkiye sosyolojisinde son dönemde çalışılan konular ve alanlar itibariyle bir çeşitlenme ve farklılaşma -ki bu olumlu bir gelişme iken-yaşandığını belirtirken, "bölmelenmişlik," yani bölümler arasında, hatta aynı bölümdeki kişiler arasında var olan kopukluğun, sosyolojinin temel sorunlarından biri olduğunu vurgulamaktadır. Benzer bir biçimde, Kayalı, Türkiye’de aydınlar arasında her işi kendiyle başlatıp, kendiyle bitirmek gibi bir eğilimin egemen olduğunu belirtmektedir. Kayalı’nın "süreksizlik" ve "hafızasızlık" olarak nitelendirdiği bu durum, Türkiye'de sosyal bilim araştırmalarının ve ürünlerinin birbiriyle ilişkilendirilememesine yol açan bir düşünsel kopukluk yaratmaktadır. Aktay da benzer bir tespitte bulunmaktadır. Aktay’a göre, Türk sosyolojisi veya akademisi içindeki pozitivist tutum (aşırı depolitizasyon), sosyolojinin hem kendi içinde hem de kendisi ile toplum arasında kurulan sınırlar bağlamında sorunlu yapı arz etmektedir. Bu durum, Türkiye'de büyük kuramsal gelenek ve okulların/ekollerin oluş(a)mamasının en önemli nedenlerinden biridir (Aktay, 2013). Türkiye sosyolojisine ilişkin bir diğer önemli tespit ise, devletin veya siyasal iktidarların entellektüel alanı belirleme inisiyatifini her daim elinde tutma çabasının, akademik alanı sınırlandırmada ve biçimlendirmedeki rolüdür. Siyasal iktidarların, genelde üniversite ile, özelde sosyolojiyle 
başlangıcından günümüze kadar kurduğu ilişki ve müdahale biçimleri de, sosyal bilimlerin Türkiye'de kurumsallaş (ama)ması üzerinde çok yönlü etkilere sahip olmuştur (Çelebi, 2016; Toprak, 2015). Türkiye'de entelektüellerinin güncel olana "aşırı ilgi duyması," "aşırı ampirisizm," "aşırı pozitivizm," "aşırı teorik-spekülatif," veya "aşırı depolitizasyon” (Aktay, 2013), "Batı'ya/dışa aşırı bağlı-bağımlı," veya "yerelden kopuk," "aktarmacı" gibi birçok 'aşırılıklar'dan mustarip olduğu yaygın bir biçimde kabul görmektedir (Kayalı, 2000; 2003; Zorlu, 2008; Sezer, 1991).

Bu çalışmalar ve tespitler, Türkiye sosyolojisinin tarihini ve entelektüel birikimini anlamak açısından oldukça değerli ve önemli katkılar sunmakla birlikte, Türkiye'de sosyolojinin nasıl ve niçin böyle bir niteliğe büründüğü konusunda süreç ve mekanizmaların yapısal bir analizini sunmaktan uzaktır. Entelektüellerin salt düşünsel üretimlerine odaklanmak, sosyolojik üretimin gerçekleştiği yapısal alanı gözardı etmek anlamına gelir. Türkiye'de sosyolojinin sosyolojisini yapmaya dönük çabanın başlangıç noktalarından biri, Türkiye'de akademik habitusun üretim ve yeniden üretim mekanizmalarının analizine odaklanmak olmalıdır. $\mathrm{Bu}$ bağlamda, akademik bir geleneğin oluşması toplumsal (makro düzlem), kurumsal/kurumlar arası etkileşim (orta düzlem) ve kurum-içi (mikro) düzlemde gerçekleşen ilişki ağlarının oluşturduğu bağlamların karşılıklı etkileşimi içinde şekillendiği söylenebilir. Toplumsal ve siyasal makro bağlam, akademik kurumların ve alanların içinde yer aldığı sosyo-kültürel ve siyasal yapıları; kurumsal bağlam, her bir kurumun tarihçesi ve kurumlar arası etkileşimin düzlemini; mikro bağlam ise, akademik alanın en küçük birimi olan bölüm veya kurum-içi ilişkilerin düzlemi olarak tarif edilebilir. Bu bağlamda, Türkiye'de sosyologların sosyoloji yapma tarzlarına ilişkin tespit edilen sorun alanları, sosyologların üretimi ve istihdam biçimlerinin hem mikro hem de makro ve orta düzlemlerinin etkileşimlerden bağımsız anlaşılamaz.

\section{Türkiye'de Sosyolojinin Akademik Kurumsallaşması}

Türkiye'de sosyolojinin akademik bir disiplin olarak başlangıcı 1900 yıllarında başına kadar gitmektedir. Sosyolojinin Türkiye'deki tarihçesi Ziya Gökalp'in 1914'de Darülfünun bünyesinde açılan İçtimaiyat kürsüsünü kurmasıyla başlar². Ancak, Birinci Dünya Savaşı ve Cumhuriyet'in ilk yıllarında yaşanan kesintiler nedeniyle sosyolojinin bağımsız bir akademik disiplin ve kürsü olarak, 1939'da Ankara Dil Tarih ve Coğrafya Fakültesi (DTCF) bünyesinde ve 1941'de İstanbul Üniversitesi bünyesinde yeniden kurulmasıla başlar. Genelde İstanbul ekolu ve Ankara ekolü olarak tanımlanan sosyoloji gelenekleri, siyasal iktidarların müdahaleleri ve kesintileriyle, 1960'lara gelindiğinde yeni üniversitelerin bünyelerinde açılan sosyoloji bölümleriyle çeşitlenmeye ve gelişmeye devam etmiştir. 1959'da Orta Doğu Teknik Üniversitesi (ODTÜ) bünyesinde kurulan sosyal bilimler programı, 1967'de Hacettepe Üniversitesi olarak kurumsallaşacak üniversite bünyesinde 1964 yllında başlayan sosyoloji eğitimi, 1971'de Boğaziçi Üniversitesi ile devam eden sosyoloji bölümlerine, 1977-1979 yılları içinde Ege Üniversitesi'nde kurulan Sosyoloji Bölümü ve daha sonra İnönü, Mimar Sinan, Atatürk, Cumhuriyet, Frrat ve Selçuk Üniversiteleri'nde kurulan sosyoloji bölümleri de dahil olmuştur. 2 Sosyoloji kürsüsünün kuruluş tarihi konusunda farklı başlangıç tarihleri tanımlanmakla birlikte, 1914 yaygın olarak kabul edilen tarihtir (bkz. Kaya,
2008). 
1991'de 12 olan sosyoloji bölüm sayısı, 1991'den sonra hızlı bir artış sergilemiştir. Yeni kurulan kamu ve vakıf üniversiteleriyle birlikte Türkiye'de sosyoloji bölümlerinin sayısı hızlı bir ivme sergilemiştir. 2011 verisine göre, 102 devlet üniversitesinin 48'inde lisans, 34'ünde yüksek lisans ve 21 'inde doktora düzeyinde; 52 vakıf üniversitesinin 10'unda lisans, 6'sında ise yüksek lisans sosyoloji eğitimi verilmektedir (Bulut, 2011: 12). Türkiye'de sosyoloji bölüm sayısı 2015 itibariyle, devlet ve vakıf üniversiteleri olmak üzere, 93’e çıkmıştır. 1991 yılında Kasapoğlu tarafından Türkiye'de sosyoloji eğitimi üzerine yapılan çalışmada, öğretim elemanı sayısı 58'i okutman ve araştırma görevlisi statüsünde olmak üzere toplam 108 olarak belirtilmektedir. Günümüzde ise, asistan ve okutmanlar hariç doktoralı öğretim üyesi sayısı 800'ü aşmaktadır.

Türkiye sosyolojine ilişkin ifade edilen "bölmelenmişlik," "süreksizlik" gibi kavramlarla tanımlanan akademik habitusu anlamak, bu habitusu var eden akademik alanın nasıl şekillendiğini anlamakla mümkün olabilir. Bourdieu, habitus kavramını, toplumsal uzayın içinde yer alan aktörlerin pratiklerinin, normlarının ve eğilimlerinin yapılandığı zihinsel yatkınlıklar seti olarak tanımlar (Bourdieu, 1995, 1996; Asimaki, ve Koustourakis, 2014; Tatlıcan ve Çeğin, 2007). Habitus hem bilincinde olduğumuz pratiklerin hem de bilincinde olmadığımız, bir tarz güdülere dönüşmüş, yani yaptığımız ama neden yaptığımız konusunda üzerinde fazlaca düşünmediğimiz pratiklerin bir bileşimidir (Waquant, 2016). Habitus kavramının analitik gücü, aktörlerin düşünsel yatkınlıklarının oluşumunda mekân, toplumsal uzayın ve tekrar edegelen pratiklerin, norm ve değerlerin sürekli etkileşimlerinin yapılandırdığı bir yapı olarak çok boyutlu faktörleri analize katmasından ileri gelmektedir. Bu bağlamda, akademik habitus, salt akademik disiplinin bilgi, beceri ve yöntemlerinin edinildiği formel bir eğitim sürecinden çok daha fazlasını içerir. Akademik habitus, akademiye dair edinilen yazılı olmayan kurallar, değerler, mesleki incelikleri, kısaca akademisyen kimliğinin ve kültürünü içeren ve kuşaklar arası etkileşimlerin bir ürünü olduğu söylenebilir. Kısaca, akademik habitusun oluşumu kolektif bir üretimdir. Akademik habitusun inşasında öğrencilik, temel sosyoloji formasyonun alındığı aşama, ileri düzeyde akademik çalışma (doktora) ve akademik istihdamın niteliği iki önemli alanı oluşturmaktadır. Bu bağlamda, akademik üretimin en önemli mekanlarının bölümler olduğu söylenebilir. Bölümler hem sosyolojik bilgi üretme mekanları hem de sosyolog üretiminin ve akademik istihdamının gerçekleştiği mekanlardır. Akademik geleneğin üretimi akademik mekanların niteliklerinden bağımsız düşünülemez. Bölümler, hem disiplinin geçmiş ve güncel bilgi birikiminin aktarıldığı, hem de akademik habitusun, "sosyolog olma" ve "sosyolog gibi davranmanın” biçimlendirildiği ve öğrenildiği mekanlardır. Bölümlerin nasıl şekillendiği ise, akademik istihdamın niteliği ve nasıl biçimlendiği ile yakından ilintilidir.

\section{Türkiye'de Akademik İstihdam Modelleri}

Merton (1968), akademinin evrensel bilimsel normlara dayanan niteliğinden ötürü, akademik kurumların işleyişinin ve ödüllerin dağıtımının da bu evrensel norm çerçevesinde, yani meritokratik normlar ekseninde şekilleneceğini belirtir (Burris, 2004). Zira, Merton’a göre bilimsel topluluk “dünyevi, maddi ödüller ve kişisel kazançlarla "lekelenmemiş”, nesnel, tarafsız ve kamu desteği alacak derecede güvenilir” bir topluluktur (Gönç Şavran, 2011, s.34). Ancak, Avrupa ve ABD'de akademik kurumlar arasındaki istihdam örüntüleri üzerine yapılan 
çalışmalar, akademik dünyanın Merton'ın idealize ettiği bu ethosun oldukça uzağında olduğunu göstermektedir (Burris, 2004; Crane, 2016). İstihdam tercihlerinde rasyonel bir biçimde işleyen bir piyasadan daha ziyade, Weber'in statü gruplarına ilişkin kuramında dile getirdiği "toplumsal kapanma" temelinde işleyen bir mekanizma daha gerçekçi bir model görünmektedir. Burris, ABD'deki akademik kurumlar arasındaki istihdam örüntüsü üzerine yaptığı çalışmada, akademik kurumlar arasında sembolik kaynakların ve prestijin dağıtımında bir tarz "toplumsal kapanma" stratejisine uygun bir işleyişin söz konusu olduğunu belirtir. Sembolik kaynak ve yaşam tarzlarının, gruba dahil olma/dışarıya kapatma gibi mekanizmaların, Bourdieu'nun işaret ettiği kültürel ve sosyal sermayelerin dağılımında ve yeniden üretiminde güç ve eşitsizliğe dayalı bir statü hiyerarşisini meşrulaştıran bir yapının akademik alanda da egemen olduğu görülmektedir (Burris, 2004). Buna göre, ABD'deki sosyoloji bölümleri arasındaki istihdam örüntülerini inceleyen Burris, prestijli kurumların prestijli kurumlardan öğretim elemanı istihdam eden bir prestij hiyerarşisini yeniden üreten bir yapının, istihdam ağının varlığını ortaya koymaktadır. Elit kurumlar sadece elit kurumlardan eleman istihdam ederken, sıralamada altta yer alan kurumlardan eleman almamakta; ancak kendi etki alanını genişletmek için kendi yetiştirdiği akademisyenleri daha düşük kurumlara transfer etmektedir.

Türkiye'de akademik bölümlerin oluşumunda ve akademik istihdamın niteliğini belirlemede üç modelin başat olduğunu belirtmek gerekir. Birincisi, devletin yüksek öğretim alanını hızlı bir biçimde şekillendirmesinin bir sonucu olarak, yurt-dışına burslu statüde ve zorunlu hizmet karşllığında doktora eğitimine gönderilen akademisyenlerin istihdamına dayanan model; İkincisi, bölümlerin kendi bünyesinde doktora programlarından mezun olan ve çoğunlukla doktora yaptığı bölümde asistan statüsünde görev yapan akademisyenlerin istihdamı dayanan istihdam modeli ve son olarak, Öğretim Elemanı Yetiştirme Programı (ÖYP) olarak tanımlanan ve Türkiye'de "merkezi" konumda yer alan üniversitelerde doktora eğitimini tamamladıktan sonra ülke içinde yeni kurulan üniversitelerde zorunlu hizmet dayalı olarak akademik istihdam modeli. Türkiye'deki akademik istihdam modeli, Batı'daki üniversitelerin istihdam modellerinden oldukça farklı bir niteliğe sahiptir. Birincisi, devletin ve merkezi iktidarın akademik istihdam sürecine müdahale etme biçimi ve belirleme gücü akademik alanın inşasında önemli bir paya sahiptir. Gerek yurt-dışında öğretim elemanı yetiştirme, gerek ÖYP modeli ${ }^{3}$ çerçevesinde gerçekleştirilen istihdam modelinde akademik kurumların veya bölümlerin tercihlerinden daha ziyade merkezi olarak belirlenen bir seçim ve istihdam modelinin başat olduğu görülmektedir. Bu model, akademik birimlerin özerk işleyişini sınırlandırma ve akademik alanı biçimlendirme konusunda cumhuriyetten günümüze devletin akademik alana "aşırı hassas" olmasının bir göstergesidir.

Diğer taraftan, doktora programı olan üniversiteler ve bölümler arasında ana eğilimin, 'ustaçrak ilişkisi’ olarak adlandırabileceğimiz model çerçevesinde lisans-yüksek lisans-doktora

\footnotetext{
3 ÖYP uygulaması 2002 yılında ilk olarak Orta Doğu Teknik Üniversitesinde başlatılmıştır. Daha sonra, Hacettepe, Ankara, Ege, Gazi, Boğaziçi ve İstanbul Teknik üniversitelerinde yürütülmüştür. ÖYP aslında yurt içi ve yurt dışı lisansüstü eğitim programlarının harmanlanmasıyla elde edilmiş bir model ile öğretim üyesi yetiştirilmesini amaçlamaktadır. ÖYP modeli, başlangıçta öğretim elemanı kadrosu talep eden akademik kurumun yönetiminin görevlendirdiği kişilerin, ÖYP programı olan üniversitelerdeki yüksek lisans ve doktora yapan öğrenciler arasından gerçekleștirilen seçime katılımları ile söz konusu iken, daha sonraki düzenlemeler bu seçimi Yüksek Öğretim Kurulu'na devredilmiş ve merkezi seçime dayalı bir modele geçilmiştir.
} 
aşamalarının çoğunlukla tümünün aynı kurumda gerçekleşmesine dayalı, 'iç-beslenmenin' (inbreeding) norm olduğu bir istihdam modelinin başat olduğu görülmektedir. Bu bağlamda, Türkiye'de akademik kurumlar arasındaki istihdam ağı yakın zamana kadar dışardan öğretim elemanı istihdamına kapalı bir niteliğe sahiptir. Görece erken dönemde kurumsallaşmasını tamamlamı̧ merkezi konumdaki üniversitelerin sosyoloji bölümlerinde tercih kendi mezununu istihdam etmek şeklindedir. Dolayısıyla, lisans, lisansüstü öğrencilikle birlikte yürütülen asistanlık sonrası öğretim üyeliği gibi tüm akademik aşamaların aynı kurumda gerçekleştiği bir akademisyen üretim tarzının yakın zamana başat model olduğu söylenebilir. 1990'dan sonra sayıları hızla artan devlet ve vakıf üniversitelerinde istihdam örüntüsü, merkezdeki üniversitelerden farkllık göstermektedir. Bu bölümlerde öğretim üyelerinin lisans ve lisansüstü eğitimleri farklı kurumlarda gerçekleştiği için kurumsal çeşitlilik yüksektir. Ancak, gelişimini hızlı tamamlayan ve doktora programı açma koşullarını sağlayan yeni akademisyen üretim mekanlarının da var olan başat istihdam modeline (iç-beslenme) kayma yönünde bir eğilim göstermektedir.

\section{Sosyoloji Bölümleri Arasında İstihdam Ağı}

Aşağıdaki grafik sosyoloji bölümlerinde aktif olarak çalışan öğretim üyelerinin lisans derecelerini aldıkları üniversitelere göre istihdam ağını göstermektedir. Grafikteki kurumları temsil eden düğmelerin büyüklüğü ve renk skalası (koyu maviden sarıya) akademisyen olarak istihdam edilen sosyoloji lisans mezunlarının kurumlara göre payını oransal olarak göstermektedir. Ayrıca, kurumlardan diğer kurumlara ilişki ağını gösteren okların rengi ve kalınlıkları ilişkinin yoğunluğunu ve etki alanlarını göstermektedir.

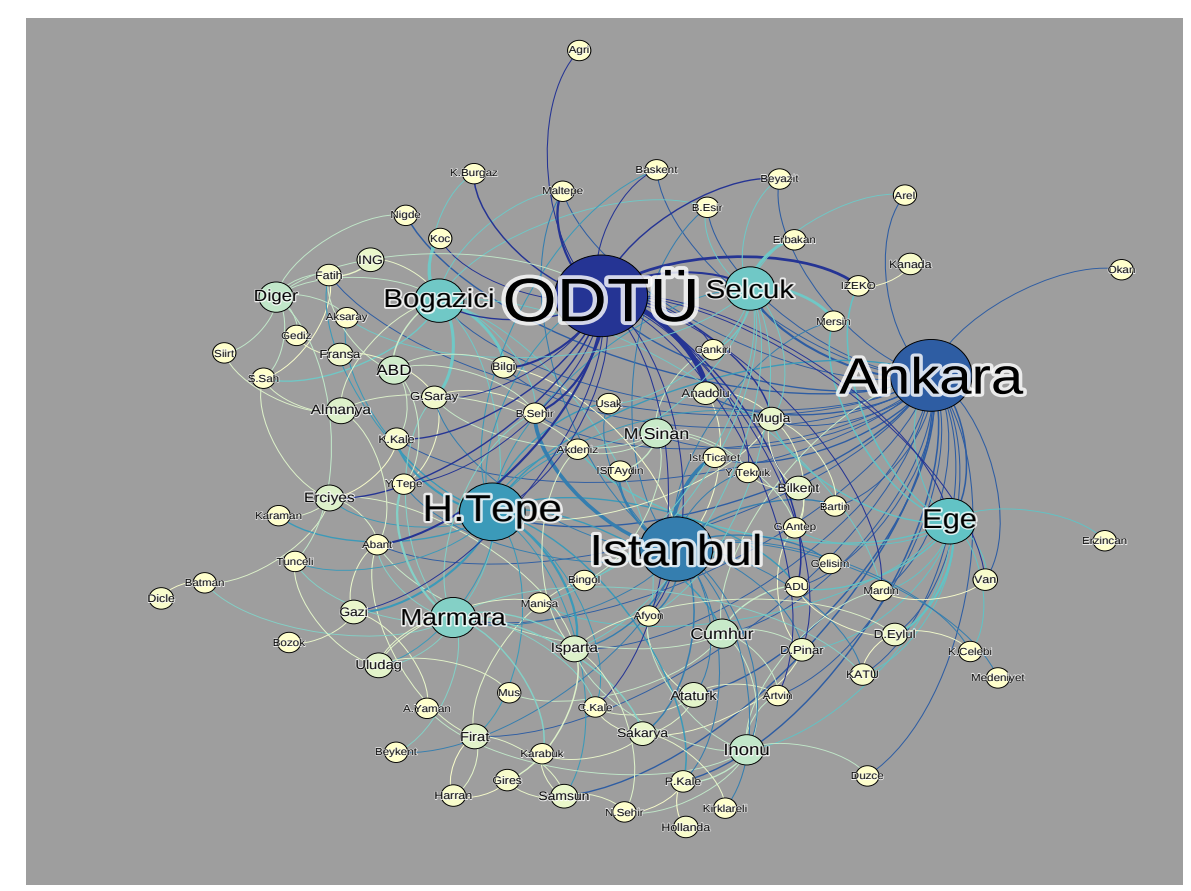

Şekil 1. Akademisyenlerin Lisanslarını Aldıkları ve İstihdam Edildikleri Bölümlere Göre ilişsi Ağları 
Buna göre, Türkiye'de sosyoloji bölümlerinde çalışan akademisyenlerin lisans derecelerini aldıkları bölümler itibari ile, bekleneceği üzere, en yüksek paya ODTÜ, Ankara, İstanbul ve Hacettepe Üniversitelerinin sahip olduğu görülmektedir. Bu merkezi konumdaki üniversiteleri Ege, Selçuk, Boğaziçi ve Marmara Üniversiteleri takip etmektedir. Üçüncü halkada ise, İnönü, Cumhuriyet ve Mimar Sinan Üniversiteleri gelmektedir. Merkezi konumdaki bölümlerin kendi etki alanlarında çevre üniversitelere kendi mezunlarını yerleştirdikleri görülmektedir. Bir anlamda, merkez üniversiteler bağlı uydu bölümlerin ortaya çıktığı söylenebilir.

Buna göre, ODTÜ'nin en güçlü ilişki ağları içinde Anadolu, Abant, Maltepe, Bilgi, Kemerburgaz, İzmir Ekonomi, Bahçeşehir, Muğla ve Adnan Menderes Üniversiteleri yer alırken, İstanbul Üniversitesi'nin en güçlü bağlarını, İstanbul Ticaret, İstanbul Aydın, Bahçeşehir, Sakarya, Cumhuriyet, Isparta ve Atatürk üniversiteleri ile tesis ettikleri görülmektedir. Hacettepe Üniversitesi ise, Gazi, Isparta SDÜ, Pamukkale, Frrat, Aksaray, Fatih ve Samsun Ondokuz Mayıs Üniversitleri; Buna karşılık, Ankara Üniversitesi ise, Samsun, Pamukkale, Atatürk, Arel ve Okan Üniversiteleri ile daha yoğun ilişki içinde olduğu görülmektedir. İkinci halkada yer alan Boğaziçi Üniversitesi mezunlarının Bilgi, Koç ve Galatasaray Üniversitelerinde; Ege Üniversitesi mezunları ise, Dokuz Eylül, Mersin, Muğla, Akdeniz, Adnan Menderes ve İzmir Ekonomi Üniversitelerinde; Selçuk Üniversitesi'nin mezunları ise Erbakan, Mersin ve Çankırı Üniversitelerinde yoğunlaştıkları görülmektedir.

Tarihsel olarak kurumsallaşmasını görece erken dönemde tamamlamış bölümlerden lisans derecesini almış olanların akademisyenliğe geçiş oranlarının yüksek olması anlaşılır bir durumdur. Ancak, burada dikkate çekilmesi gereken en önemli husus, merkez konumdaki üniversitelerin birbirleri arasında yok denecek düzeyde sınırlı bir ilişkinin varlığıdır. Merkezi konumdaki bölümlerin kendi mezunlarını farklı üniversitelere yerleştirirken, kendi lisans mezunları dışında öğretim elemanı alma konusunda oldukça isteksiz oldukları görülmektedir. Dışarıdan istihdama en kapalı üniversiteler sırasıyla, İstanbul, Hacettepe ve Ege, dışarıya en açık üniversitenin ise Boğaziçi olduğu görülmektedir.

Doktora derecelerine göre istihdam örüntülerine bakıldığında (bkz. Şekil 2) bazı belirgin farklılıklar ve benzerlikler ortaya çıkmaktadır. Lisans dağılımında olduğu gibi, doktora açısından İstanbul, ODTÜ, Hacettepe ve Ankara ön plana çıkmaktadır. İkinci halkada ise, Ege, Mimar Sinan, Marmara ve Sakarya Üniversiteleri gelmektedir. Ancak, lisans dağılımından farklı olarak, yurt-dışı doktoralı öğretim üyelerinin payı Türkiye sosyolojisi içinde azımsanmayacak bir orana sahip olduğu görülmektedir. 


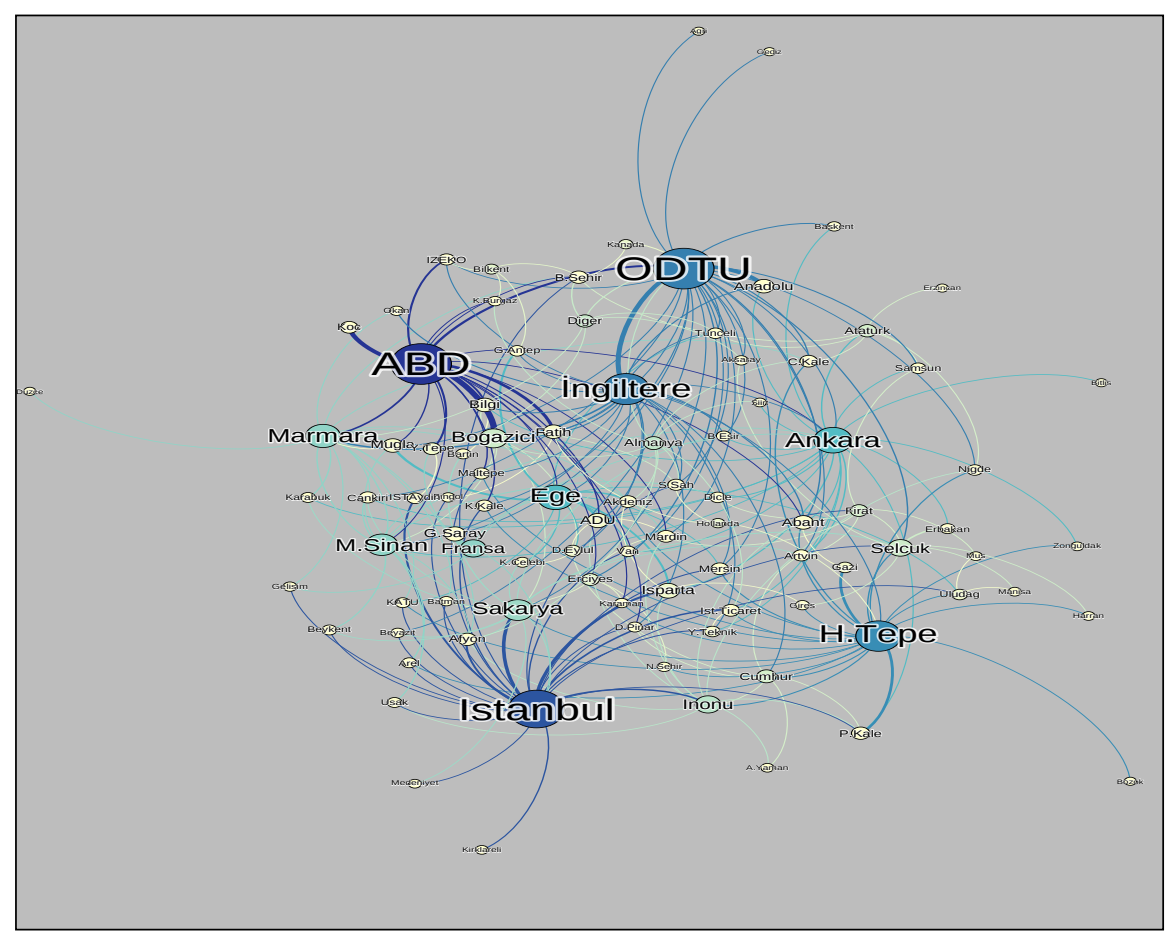

Şekil 2. Akademisyenlerin Doktoralarını Aldıkları ve İstihdam Edildikleri Bölümler Göre ilişski Ağları

Akademisyenlerin başta ABD, İngiltere ve Fransa olmak üzere Kanada, Almanya ve Hollanda gibi Batılı ülkelerden doktora derecesini aldıkları belirtilmelidir. ABD ve İngiltere menşeili doktoralı akademisyenlerin çalıştıkları kurum açısından ilişki ağlarına baktığımızda, Boğaziçi, Bilgi, Koç, Fatih Üniversiteleri küresel sosyoloji bağlantıları en güçlü bölümleri arasındadır. Bunları, ODTÜ, Yeditepe, Maltepe, İzmir Ekonomi ve Muğla izlemektedir. Fransa ve Galatasaray arasındaki ilişki özel bir konuma işaret etmektedir ve kurumsal uzamda neredeyse üst üste bir çakışma söz konusudur. Diğer taraftan bir diğer önemli doktora üretim merkezi İngiltere'dir. İngiltere'den doktora derecesini alanlar içinde ODTÜ en yüksek paya sahip olduğu görülmektedir. ODTÜ’yü, Fatih, Bilgi, Marmara, Akdeniz, Muğla ve Adnan Menderes Üniversiteleri izlemektedir. İstanbul Üniversitesi, Hacettepe, Ankara ve Ege Üniversiteleri yurtdışı ile en zayıf bağlara sahip üniversiteler arasında gelmektedir. ODTÜ ve Boğaziçi Üniversiteleri ile İstanbul Üniversitesi'nin ağ üzerinde konumlanmaları küresel ve yerel arasındaki karşıt konumlamaları göstermektedir. Ankara ve Ege'nin konumu ise bu konumlanmaların ortasında bir yerde yer almaktadır. Ancak, her durumda merkez konumdaki sosyoloji bölümlerinin birbirleri ile ilişki ağının son derece sınırlı ve zayıf olduğu görülmektedir.

Lisansa dağılımına benzer bir örüntü doktora açısından da belirginleşmektedir. Merkez konumdaki bölümler ve bu bölümlerle güçlü bağları olan uydu sosyoloji bölümleri ortaya çıkmaktadır. Örneğin, İstanbul Üniversitesi, Sakarya, Isparta, Afyon, İnönü, İstanbul Aydın, İstanbul Ticaret ile görece güçlü bağlara sahipken, Hacettepe ise, Pamukkale, Gazi, Selçuk, Niğde, Cumhuriyet ve İnönü Üniversiteleri ile ilişkilerinin güçlü olduğu görülmektedir. Buna karşılık, Ankara ise, Artvin, Samsun, Atatürk, Dicle ile, Ege sosyoloji ise, Akdeniz, Muğla, Adnan Menderes, Dokuz Eylül, Katip Çelebi, Gaziantep ve Isparta ile güçlü bağlantılara sahip 
olduğu görülmektedir. Lisans da olduğu gibi burada da temel yönelimin kendi mezununu tercih etmenin bir norm olarak karşımıza çıkmasıdır. Merkezde konumlanan bölümler arasında farklı bölümlerden doktoralarını alan öğretim üyelerini tercih etmek konusunda isteksizlik başat eğilimdir. Bu hususta, ODTÜ bir istisna gibi durmaktadır. Kendi doktora programı olduğu halde, dışarıdan istihdama en açık sosyoloji bölümü ODTÜ görünmektedir. Ancak, istisna gibi görünen bu durum, aslında istisna saymamak gerek; Zira, ODTÜ’nün istihdam tercihinde ortaya çıkan temel eğilim, kendi lisans öğrencilerini yurt-dışında doktoraya özendirmek ve yine kendi lisans mezunları arasından doktora yapmış öğretim üyelerini istihdam etmektedir.

\section{Sonuç}

Türkiye'de son yıllarda sayıları hızla artan üniversitelerin bünyesinde kurulan sosyoloji bölümleri farklı istihdam modelleri ve tercihleri ile karmaşık bir kurumlar arası ilişki ağlarının ortaya çıkmasına neden olmuştur. Bu artan karmaşık etkileşime rağmen, bazı yapısal süreklilikler ve yeni etkileşimlerin ortaya çıktı̆̆ını veriler belirgin bir biçimde ortaya koymaktadır. Bu bağlamda analizlerden çıkan birkaç tespiti tekrar belirtmekte fayda var. Hem öğretim üyelerinin lisans ve doktora derecelerini aldıkları ve çalıştıkları kurumlar arasındaki etkileşimler haritası çok net bir biçimde Türkiye sosyolojisi içinde iki kutbun varlığını ortaya koymaktadır. Birincisi, ODTÜ, Boğaziçi ve İstanbul ve Hacetepe Sosyoloji bölümleri hem yüksek etki gücüne sahip hem de akademik uzayın iki karşıt kutbunda küresel-yerel bir aksta konumlanmaktadır. ODTÜ, Boğaziçi gibi küresel sosyoloji bağlantıları güçlü, özellikle ABD ve İngiltere gibi önemli akademik merkezlerden doktoralı öğretim üyelerini istihdam etmekte ve yabancı dilde eğitim veren özel/vakıf üniversitelerine öğretim elemanı transfer etmektedir. Buna karşılık, İstanbul ve Hacettepe yerel ve ulusal ölçekte güçlü bağlantılara sahip görünmektedir. İstanbul ve Hacettepe'nin etki alanlarının, Sakarya, İnönü, Gazi, Cumhuriyet, Pamukkale gibi üniversiteler olduğu görülmektedir.

Türkiye'de sosyoloji bölümleri arasında istihdam ağları açısından belirtilmesi gereken bir diğer husus ise, merkez ve çevre açısından iki farklı temel örüntü ortaya çıkmaktadır. Birincisi, İstanbul, Ankara, ODTÜ, Hacettepe, Boğaziçi ve Ege gibi merkezde konumlanan bölümler, kendi içinde görece yüksek homojenite ve merkezde konumlanan bu üniversitelerdeki bölümler arasındaki geçişkenliğin son derece düşük olduğu bir yapı ortaya çıkmaktadır. İkincisi, çevrede yeni kurulan, yer yer merkezdeki üniversitelerin uydusu görüntüsünde olan ve görece daha heterojen bir akademik kadro barındıran çevredeki kurumlar yer almaktadır. Bu bağlamda, Türkiye'de "bölmelenmişlik ve süreksizlik" sorunu ilginç bir muammayı barındırmaktadır. Merkezde lisans ve doktora formasyonun özellikleri ile istihdam örüntüsünün yüksek homojenliği ve düşük geçişkenlik düzeyinin akademik bir habitusu aktarmak ve dolayısıyla bir akademik gelenek oluşturabilmesinin maddi altyapısına sahip olduğu söylenebilse dahi, bu durum bölümler içinde böylesi bir geleneğin üretilmesine yol açmamıştır. Diğer taraftan, çevrede yeni kurulan ve hızlı bir artış sergileyen bölümler görece daha heterojen bir nitelik sergilerken, merkezdeki bölmelenmişliği yeniden üreten bir nitelik sergilemektedir. 
Türkiye'de sosyoloji, Fransa ve Birleşik Devletler gibi gelişmiş ülkelerdeki kurumsallaşmaya paralel, eş zamanlı ve erken bir dönemde üniversite sisteminin bir parçası olarak gelişme gösteren sosyolojinin, kendine özgü bir akademik geleneğe sahip olup olmadığı konusu üzerine bir ittifak olmamakla birlikte, cumhuriyetten günümüze siyasal iktidarların akademik alana müdahale etme biçimlerinin, genelde üniversitelerin, özelde ise sosyal bilimlerin görece özerk bir gelenek oluşturmasına ket vurduğu söylenebilir. Türkiye'de akademik istihdamın ana örüntülerine bakıldığında, hükümetlerin belirleyici bir paya sahip olduğu görülebilir. Diğer taraftan, bölümlerin kendi tercihleri söz konusu olduğunda ise, içten-beslenme ana eğilim olarak ortaya çıkmaktadır ${ }^{4}$. Türkiye'de akademisyen üretme tarzının, özellikle içten beslenmeye dayalı modelin, kuşaklar arası bir süreklilik ve yoğun etkileşimin varlığı düşünüldüğünde, akademik bir gelenek üretmeye uygun bir yapı arz ettiği düşünülebilir. Ancak, ne merkezde konumlanan bölümlerdeki yüksek homojenite ne de çevredeki bölümlerdeki yüksek kurumsal farklılık bölümler bazında epistemik geleneklerin inşasına elverişli yapı ortaya çıkaramamıştır. $\mathrm{Bu}$ durumu üreten en önemli faktör, bölümlerin gelenek oluşturma ve aktarmanın maddi ve kurumsal altyapısına sahip olmasına rağmen, sosyoloji bölümlerinin kuruluşundan itibaren akademik üretim ve istihdam süreçlerinde bölümlerin özerkliğinin olmaması ve iktidarın müdahalelerine sürekli açık olmasının bir sonucu olarak kurumlar arası ve bölüm içi rekabetin "episteme"lere dayalı akademik bir rekabet ve dayanışmadan ziyade, iktidar ile eklemlenme ve dışlanma süreçlerinin belirleyici olmasından ileri geldiği söylenmelidir.

Sosyoloji bölümlerinin oluşumları ve ilişki ağları bağlamında, Osmanlı'dan cumhuriyete geçişle birlikte, sosyoloji "ulusal toplumun" ideolojik altyapısını oluşturma görevi üstlenmiştir (Toprak, 2012). Dolayısıyla, Türkiye'de "bölmelenmişlik" ve "süreksizlik" olarak tanımlanan durum, aslında bir sorun olmaktan daha ziyade cari akademik habitus'un olağan işleyiş biçimidir. Bu bir patoloji veya anomaliden daha ziyade, iktidar seçkinlerinin akademik alana müdahale etme biçimlerinin yapılandırdığı bir süreçtir. Türkiye'de epistemik cemaatlerden ziyade, dar anlamıyla siyasallaşan bir akademik rekabetin yeniden üretimine dayalı bir kurumsallaşmanın varlığından söz edilebilir. Kısacası, iktidarların akademik alana çok yönlü müdahaleleri, dışa kapanma ve içten beslenmeyi derinleştirmekte ve bu durum alanın özerkliğini ve akademik geleneklerin oluşmasını zayıflatan bir etkiye sahip olmaktadır.

\section{Teşekkür:}

Araştırmanın verilerinin derlenmesinde ve Türkiye sosyolojisi üzerine entelektüel katkılar için Berivan Binay, Uğur Binici, Resul Taş̧̧’ya; emek ve ayrıntılı eleştirel katkıları için anonim hakemlere; Her aşamada yazı konusunda teşvik, entelektüel katkısı ve desteği için Roza’ya; teşekkürlerimi sunarım. Yazıdaki eksiklik ve hata elbette yazara aittir.

\footnotetext{
${ }^{4}$ Kuşkusuz akademik istihdam konusunda, diğer akademik alanlar bağlamında da daha geniş ölçekli çalışmaların yapılması gereklidir. Böylesine genişletilmiş ve kapsamlı bir çalışma, bize Türkiye'deki akademik istihdam ilişki ağları ve bilim kurumlarının inşasında başat aktör ve yapıların neler olduğunu ortaya koymaya elverişli veriler sunacaktır. Zira, son yıllarda her kente bir üniversite açma politikasının bir yansıması olarak, üniversite üzerinde yerel güç ağlarının, nüfuzlu ailelerin akademik istihdam ve akademik kurumsallaşma tercihleri üstünde ne tür etkilere sahip olduğu başlı başına ilginç bir araştırma sorusu olabilir. Bu çalışmada sosyoloji özelinde böylesi bir veri elde bulunmamakla birlikte, bu konunun daha ayrıntılı ve sistematik araştırmalar ile araştırılması önem arz etmektedir. Bu bağlamda, bu konuya dikkatimi çeken anonim hakeme görüş ve eleştirileri için teşekkürlerimi belirtmek isterim.
} 


\section{Kaynakça}

Akpolat, Y. (2013). Erken Cumhuriyet Döneminde Türk Sosyolojisi. M. Çağatay Özdemir (Ed.), Türkiye'de Sosyoloji içinde (s. 75-95). Eskişehir 2013.

Akşit, B. (1986). Türkiye'de Sosyoloji Araştırmaları: Bölmelenmişlikten Farklılaşma ve Çeşitlenmeye. Sevil Atauz, (Der), Türkiye'de Sosyal Bilim Araştırmalarının Gelişimi içinde (s. 195-232). Ankara: Türk Sosyal Bilimler Derneği.

Aktay, Y. (2013). Türk Sosyoloji Tarihine Eleştirel Bir Katkı. İstanbul: Küre.

Alver, K. (2014). Türk sosyolojisi: Tarzlar, İçerikler, Sınırlar. Sosyoloji Divanı, 2(4), 25-38.

Asimaki, A. \& Koustourakis, G. (2014). Habitus: An attempt at a thorough analysis of a controversial concept in Pierre Bourdieu's theory of practice. Social Sciences, 3, 121-131.

Bourdieu, P. (1996). Distinction: A Social Critique of the Judgement of Taste. Londra: Rourledge.

Bourdieu, P. (1995). Pratik Nedenler. H. Tufan (Çev.). İstanbul: Kesit.

Bulut, Y. (2011). Türkiye’de Sosyoloji Eğitimi. Sosyoloji Dergisi, 23(3), 1-18.

Burris, V. (2004). The academic caste system: Prestige hierarchies in $\mathrm{PhD}$ exchange networks. American Sociological Review, Vol. 69 (2): 239-264

Coşkun, I. (1991). Sosyoloji Bölümünün Tarihine Dair. I. Coşkun (Yay. Haz.). 75. Yılında Türkiye'de Sosyoloji içinde (s. 13-23). Ankara: Bağlam.

Crane, D. (2016). Sosyal Sınıf Kökeni ve Akademik Başarı: İki Tabakalaşma Sisteminin Akademik Başarı Üzerine Etkisi. B. Balkız ve V. S. Öğütle (Ed), Bilim Sosyolojisi Incelemeleri: Temel Yaklaşımlar, Kavramlar ve Tartışmalar içinde Ankara: Doğu-Batı.

Çelebi, N. (2016). Sosyoloji Tarihimize Kısa Bir Bakış. Sosyoloji Konferansları, (52), 0-0. Doi: $10.18368 / \mathrm{Iu} / \mathrm{Sk} .62303$.

Dépelteau, F. \& C. Powell. (Eds). (2013). Applying Relational Sociology: Relations, Networks, and Society. New York: Palgrave MacMillan.

Ergun, D. (1985). Türkiye'de Cumhuriyet Dönemi'nde Sosyoloji ve Gelişmesi. Cumhuriyet Dönemi Türkiye Ansiklopedisi C. 8 içinde s. 2161.

Gökçe, B. (2000). Türkiye'de Sosyolojinin Gelişimi ve Örgütlenme Süreci. Sosyoloji Araştırmaları Dergisi, (1-2), Ankara 2000, s.74.

Gönç-Şavran, T. (2011). İşlevselcilik-II: Parsons Sonrası İşlevselcilikte Gelişmeler. Serap Suguur (Haz.), Modern Sosyoloji Tarihi. Eskişehir: Açıköğretim.

Kaçmazoğlu, H. B. (2003). Türk Sosyoloji Tarihi II: II. Meşrutiyetten Cumhuriyete. Ankara: Anı. 
Kaçmazoğlu, H. B. (2010). Türk Sosyoloji Tarihi Üzerine Araștrrmalar. İstanbul: Kitabevi.

Kasapoglu, A. (1999). 60 Yılllk Gelenek DTCF'de Uygulamalı Sosyoloji: (Berkes- Boran-ÇağatayGüler-Nirun). Ankara: Ümit.

Kaya, T. (2008). İçtimaiyat'tan sosyolojiye: IÜEF Sosyoloji Bölümü’nün tarihine ve sosyoloji dergisine dair. Türkiye Araştırmaları Literatürü Dergisi, 6(11): 713-730.

Kongar, E. (1998). Türk Toplum Bilimcileri. Istanbul: Remzi Kitabevi.

Kayal, K. (2003). Türk Düşünce Dünyasında Yol Izleri. Istanbul: Iletiş̧im.

Kayalı, K. (2000). Türk Düşünce Dünyasının Bunalımı. İstanbul: İletişim.

Memis, P. \& Sağır, A. (2013). Yükseköğretimde yeni(lenmis) istihdam örneği olarak ÖYP. International Journal of Human Sciences, 10(1), 74-100.

Merton, R. (1968). The matthew effect in science. Science, 159, 56-63.

Merton, R. (1973). The Normative Structure of Science. Norman W. Storer (Ed.), The Sociology of Science içinde. Chicago: University of Chicago.

Özdemir, M. Ç. (Haz.). (2008). Türkiye’de Sosyoloji. Ankara: Phoenix.

Scott, J. (2000). Social Network Analysis: A Handbook. New York: Sage.

Sezer, B. (1991). Türk Sosyolojisinin Önündeki Sorunlar. I. Cosksun (Haz.), 75. Yllında Türkiye'de Sosyoloji içinde. Ankara: Bağlam.

Şahin, M. C. (2017). Türk Sosyolojisinin Kısa Tarihi: Dönemler, Şahıslar ve Ana Yönelimler. İslâmi İlimler Dergisi, 12(1), 7-41.

Tatlıcan, Ü. \& Çeğin. G. (2007). Bourdieu ve Giddens: Habitus veya Yapının İkiliğii. Güney Çeğin, Emrah Göker, Alim Arlı, Ümit Tatlıcan (Haz.) Ocak ve Zanaat: Pierre Bourdieu Derlemesi içinde. İstanbul: İletişim.

Toprak, Z. (2012). Darwinden Dersime: Cumhuriyet ve Antropoloji. İstanbul: Doğan Kitap.

Wacquant, L. (2016). A concise genealogy and anatomy of habitus. The Sociological Review, 64(1), 64-72.

Wasserman, S. \& Faust, K. (1994). Social Network Analysis: Methods and Applications. New York: Cambridge University. 